\title{
A Study on the Current Status of Chinese Legal Education
}

\author{
Min Li \\ Nanchang Institute of Science \&Technology, Nanchang, Jiangxi, 330108
}

Keywords: Legal education, Current status, Promotion advises.

\begin{abstract}
With the continuous development of Chinese social economy, legal education in China is attached with more and more importance. The construction of a legal state has been regarded as a vital task. Most colleges and universities have set up law major, proving numerous legal talents to the society, judiciary authorities, enterprises and so on. Although the course teaching of law major has been designed strictly, in practice, there are still some shortages. This paper will analyze the current status of Chinese legal education and then put forward several pertinent promotion advises.
\end{abstract}

\section{Introduction}

Legal education is an important part of Chinese higher education. It is an important path to lead students to enter legal fields and an imperative step to be legal professionals. It doesn't only contain theoretical knowledge that is taught in classes, but also include corresponding practical education. After some several major reform and development, Chinese legal education has gradually formed a system with Chinese unique characteristics. Although it accommodates to our country's basic needs for legal talents, when it confronts with various challenges and trials, problems still exist and demand an urgent solution. In the following part, this paper will explore the current status of legal education in our country, analyze the existing problems and shortages and then propose pertinently some suggestions and advises.

\section{An Overview of Chinese Legal Education}

In legal education, the teaching mainly aims to impart theoretical knowledge of law, cultivate legal thinking ability and provide excellent legal professionals. Different from western developed countries, in federal period, there is no perfect legal system in our country, let alone legal education. Until the establishment of New China in 1949, the modernization of legal education was gradually realized. However, due to the detriment of 10 years of cultural revolution, the overall education in our country was disrupted and the legal system was subject to varying degrees of negative impacts. After the cultural revolution, with the implementation of national reform and opening-up policies, higher education was in a booming development. Besides, subject system, teaching contents, teaching methods and so on were experiencing a leap-forward development. Through a long period of recovery, reconstruction and reform, at present, Chinese legal education has basically formed a comparatively stable and standardized system, which gradually meets the society's needs for legal talents.

\section{The Current Status of Chinese Legal Education}

With the continuous development of Chinese social economy, driven by social needs and benefits, law major has become very popular. Most colleges and universities have set up a law school and law major, even in some universities dominated by finance and economies, foreign language, science and engineering. However, in the term of teaching faculty condition and campus hardware, some schools are not qualified to set up law major. A blind and large increase of law majors can not guarantee the quality of legal education. Those college graduates who have received 
unprofessional and nonstandard legal education can not satisfy and accommodate to the social demands for legal talents which will hinder, to some extent, these students' legal career pursuits. Legal education on various levels is not conducive to the cultivation of law professionals. According to statistics, the quantity of students majoring in law has exceeded social needs and many of them are not able to engage in work related to law.

At present, higher education in our country has entered the "mass" stage. In the process of teaching, more attention is paid to popularized basic theoretical knowledge and "elite" education is placed in master and doctoral stage. In fact, legal education in colleges and universities is apt to impart basic legal knowledge to students, while the cultivation of professional thinking and skills is inadequate. Moreover, students tend to take it for granted that as long as they recite legal provisions fluently, they can pass examinations. It will turn students to be incompetent for highly specialized work when they enter the society. Among all graduates majoring in law, those who are admitted to be civil servants engaging in public prosecution work or those who go in for work related to law in enterprises are far less than the total number of graduates. In our country, the contradiction between "popularized" and "elite" education results into a serious shortage of high-end legal professionals. Besides, the surplus of low-end legal talents is also an urgent problem to be changed and developed.

In traditional legal education, classes are dominated by teachers' teaching of theoretical knowledge and there are insufficient chances for students to practice. Therefore, talents cultivation in most colleges and universities is out of line with enterprises in the society, failing to satisfy social needs for skilled talents. In most universities, law schools have set up core and basic courses in accordance with the education outline. Their teaching of theoretical knowledge is considered to be very thoughtful, while the design of practical courses is defective. Practical courses like Litigation Skills, Negotiation Skills and Practical Law tend to be a formality. Moreover, some schools just ask a certain length of social practice, but will not implement strict requirements and assessment on its authenticity and effectiveness, which brings about the formality of internship system. Results and scores are the main factors to be considered in the education system in our country, making the courses teaching design difficult since legal education stresses practice more. Teachers usually take the cultivation of examination-oriented talents seriously, but ignore to train students' application ability of professional skills.

With the continuous development of economic globalization, the cooperation and competition between China and foreign countries in fields like politics, economy, technology etc. are increasing which augments the needs of international laws. At present, legal education in China is not only to meet the requirements of "rule a country by law" and "legal society" to cultivate legal professionals, but also foster legal talents for our country to positively develop intentional economy, respond against external challenges and deal with international legal affairs. In recent years, under the guidance of provisions of education outline in our country, legal education in universities constantly develops. However, when learning international laws, students are required to be proficient in foreign language at a high level and there are no corresponding alternation in teaching requirements as well as methods. Students are in a lack of contact with legal education of foreign countries, being isolated from internationalized reality and making legal education in China in a short of international competitiveness. When students enter the society, they will fail to be competent to deal with international affairs once they are unable to apply international legal knowledge.

\section{Methods to Improve the Level of Chinese Legal Education}

In view of the fact that most universities have set up law major with large number of students but its overall quality varies, in order to change the current status that most graduates majoring in law are at a low-end level and high-end legal professionals are fairly less, in the premise of ensuring and improving the quality of legal education, firstly, the enrollment scale of law major needs to be controlled and the major threshold should be raised. It is proposed to put the starting point in the undergraduate education. The overall quality of students will be improved once the scale of enrollment is controlled. Secondly, on the basis of popularized education, modes like professional and practical education can be added to improve legal education quality. Lastly, it is worth 
consideration to transfer gradually the stress of legal education to graduate study, which will accelerate those students to continue their study and then improve the whole level of law major.

Legal education doesn't only impart theoretical knowledge that is needed be a legal worker, but also cultivate students' legal practice ability and make them accommodate to and engage in legal works when they enter the society from campus. Firstly, universities can cooperate with social enterprises, recommend students to law firms or enterprises to practice in positions related to legal affairs during their internship. In this way, students are able to adapt to social needs of legal professionals and have a clearer recognition of legal affairs. In addition, it is feasible to employ experienced practicing lawyer and so on to teach and communicate with students. The interaction will strengthen the connection between students and society, helping them to absorb more extra-curriculum knowledge. Lastly, the universities should regularly organize students to public prosecution authorities like court and procuratorate to do observation learning which can offer a more direct recognition and stimulate students' learning motivation to plunge themselves to public prosecution career.

At present, many enterprises in the society reflect that a lot of graduates majoring in law generally lack operational and practical ability and fail to solve flexibly legal problems. They apply legal provisions mechanically, do not consider problems in combination with actual situations and lack abilities to deal with emergencies and complex problems. Graduates majoring in law generally require more than three years' practical experience to completely adapt to the needs of handling legal affairs. In order to reduce the time that graduates accommodate to legal affairs after they enter the society, legal education curriculum should include practical law courses, for example, it is advised to set up a mock trial and so on to cultivate litigation skills, negotiation skills and business practical application ability. Besides, in the design of teaching contents, it is suggested to reduce theoretical teaching, then combine more actual cases to develop students' thinking ability and guide them to solve practical problems flexibly with legal provisions.

In order to improve the international competitiveness of legal education in our country, we must put forward higher requirements on students' foreign language ability. They need to possess enough understanding of foreign legal literature and be able to write legal documents. During teaching, more legal education cases from western countries and foreign trade should be applied to various teaching methods like mock trial. In this way, students are able to adapt to legal knowledge in advance which will lay a good foundation for their future entry into society. Moreover, it is required to pay attention to the training of students' foreign language and increase the analysis of foreign legal knowledge and cases which definitely can enhance the international competitiveness of Chinese legal education.

In our country, the traditional teaching is always teacher-centered, lacking enough opportunities for students to present or dominate the class to do academic research. In order to improve the effectiveness of legal education and arouse students' initiative to learn legal knowledge, it is asked to improve classroom teaching methods, adjust teaching contents pertinently, then take a creative teaching method to activate class and improve teaching efficiency. In accordance with the strong practical characteristic of law major, we must avoid indoctrination teaching method to impart theoretical knowledge but should take a more interactive way, for instance, through case study, debate, group presentation and other forms, students' comprehensive case analysis ability and legal practical application ability can be well trained.

\section{Conclusion}

Through the above discussion on the current status of legal education in our country and analysis of existing problems, I put forward some suggestions and advises. I believe, the legal education reform in China still needs to develop continuously and deeply. With the constant development of social economy, people's ideological level is increasing and legal professionals mean a lot to the construction and perfection of democratic nomocracy system. Legal education is the main method to cultivate and provide legal professionals whose importance is quite self-evident.

While with good development opportunities, legal education is also threatened with many 
challenges. So far, it still can not meet social needs for legal professionals and is out of line with social practice etc. In order to solve these current existing problems, in the process of reform and development, we should learn advanced experience from foreign countries, integrate international and social needs, as well as cultivate more all-around practical legal talents.

\section{References}

[1]Luo Chunju. An Exploration of Challenges and Opportunities of Modern Legal Education in China [J]. Charming China, 2014,(17): 303-303.

[2]Cai Shipeng.The Analysis of Current Status and Existing Problems of Legal Education in China [J]. Popular Science: Science Education, 2016,(6).

[3]Li Qing. The Current Status and Reform Suggestions of Legal Education in China[J]. Jin Tian, 2016,(5).

[4]Zhao Shujun. The Existing Problems and Reform Measures of Legal Education in China[J]. Legal System and Society, 2017,(8). 